\title{
Amino sugars in suspended particulate matter from the Bay of Bengal during the summer monsoon of 2001
}

\author{
Loreta Fernandes, Fraddry D'Souza, S G P Matondkar and Narayan B Bhosle* \\ National Institute of Oceanography, Dona Paula, Goa 403 004, India. \\ *e-mail: bhosle@nio.org
}

Amino sugars (AS) are important constituents of organic matter. However, very little is known about their cycling in marine waters. In this research, we assessed the distribution and cycling of these compounds in waters of the Bay of Bengal. For this purpose, samples of suspended particulate matter (SPM) were collected from 8 depths (surface to $1000 \mathrm{~m}$ ) at 6 locations during the 166th cruise of the ORV Sagar Kanya in the Bay of Bengal in July/August 2001. The SPM samples were analysed for particulate organic carbon (POC), particulate nitrogen (PN) and AS concentrations and composition. The AS varied between 0.4 and $17.5 \mathrm{nmol} / \mathrm{l}$. Concentrations were high in the surface waters and generally decreased with increasing depth. AS concentration decreased from the south to north. AS accounted for 0.01 to $0.71 \%$ and 0.05 to $2.37 \%$ of POC and PN, respectively. Rapid decrease in AS-C\% and AS-N\% with depth indicates that these compounds were preferentially degraded relative to bulk POC and PN. The composition of AS suggests that glucosamine (GLU-N) and galactosamine (GAL-N) were present in the surface SPM samples, and their abundance decreased from surface downwards. Relatively, low values of GLU-N/GAL-N ratio indicate that the organic matter was mostly derived from the detritus of micro-organisms. Our data suggest that chitin, a polymer of the glucosamine produced by many marine organisms was not the major source of AS in the Bay. Rapid cycling of these compounds indicates their importance in the cycling of nitrogen in marine waters.

\section{Introduction}

Amino sugars (AS) are unusual carbohydrates as they contain nitrogen. They are derived from many sources including microbial cell wall as peptidoglycan, lipopolysaccharides and pseudopeptidoglycan (Brock et al 1994). AS are also important constituents of many biopolymers such as polysaccharides, glycoproteins and glycolipids (Sharon 1965). Moreover, chitin, a polymer of amino sugar, N-acetyl glucosamine (Muzzarelli 1977; Benner and Kaiser 2003) is produced by many marine organisms (e.g., copepods and other crustaceans), and may thus form an important source of amino sugars in marine waters. Because of this, it is generally believed that, AS are widespread constituents of marine organic matter. Furthermore, most N in marine and dissolved organic matter resides in amide functional groups, which are common to combined amino acids and acetylated amino sugars (McCarthy et al 1997; Benner and Kaiser 2003). Hydrolysable amino acids account for $<15 \%$ of dissolved organic nitrogen in seawater, suggesting that AS could be important in the marine $\mathrm{N}$ cycle (McCarthy et al 1997). The distribution and cycling of AS in sedimenting particles and marine sediments have been well documented (Belluomini et al 1986; Haake et al 1992; Jennerjahn and Ittekkot 1997; Hashimoto et al 1998; Gupta and Kawahata 2000). Conversely, little is known about the distribution of AS in the SPM of marine waters (Muller et al 1986; Benner and Kaiser 2003; Unger et al 2005). For example, studies carried out in the Pacific and Atlantic Oceans suggest that AS of the

Keywords. Suspended particulate matter; organic matter; particulate nitrogen; amino sugars; micro-organisms; Bay of Bengal. 
SPM are rapidly utilized during the transport of the organic matter to greater depths (Benner and Kaiser 2003). Therefore, studies on AS will provide useful information on their distribution and cycling in marine waters.

There are numerous studies describing the physical, chemical and biological characteristics of the Bay of Bengal (Kumar et al 2002; Madhupratap et al 2003; Kumar et al 2004). In contrast, only a few studies have focused their attention on the characterization of organic matter with particular reference to the bulk parameters such as organic carbon, nitrogen, carbohydrates and proteins in the Bay (Nandakumar et al 1987; Bhosle and Dhople 1988; Bhosle et al 1992; Unger et al 2005). From this, it is evident that little is known about the molecular level characterization, distribution and cycling of organic matter in the Bay of Bengal. Therefore, the aims of the present study were to:

- assess the spatial and depth related distribution of amino sugars,

- identify the composition of amino sugars and

- evaluate the cycling of amino sugars in the Bay.

Such detailed studies will provide useful information about the dynamics, nutritive value, nature and degradation state of AS containing organic matter.

\section{Material and methods}

\subsection{Description of the study area}

Bay of Bengal (BOB) is a semi-enclosed tropical basin in the northern Indian Ocean. It is bounded by the Indian Peninsula and Sri Lanka on the west and by the Andaman-Nicobar islands and Burma on the east. The uniqueness of the Bay is the reversing monsoons that cause seasonal changes in circulation and weather. Furthermore, the Bay receives large quantities of fresh water influx $\left(1.6 \times 10^{12} \mathrm{~m}^{3} \mathrm{yr}^{-1}\right)$ from the major rivers such as, Ganges, Brahmaputra, Mahanadi, Pennar and Cauvery (Subramanian 1993). The average annual discharges are very high for the GangesBrahmaputra and relatively low for the Pennar and Cauvery (Rao 1985). The fresh water inputs result in the stratification of the upper $50 \mathrm{~m}$ of the water column (Kumar et al 2002). Moreover, the frequently occurring cyclones are additional sources of phosphate and nitrates in the surface waters of the Bay (Vinayachandran and Mathew 2003). This nutrient supply results in the formation of intense localized blooms. Upwelling has been observed along the western boundary of the Bay

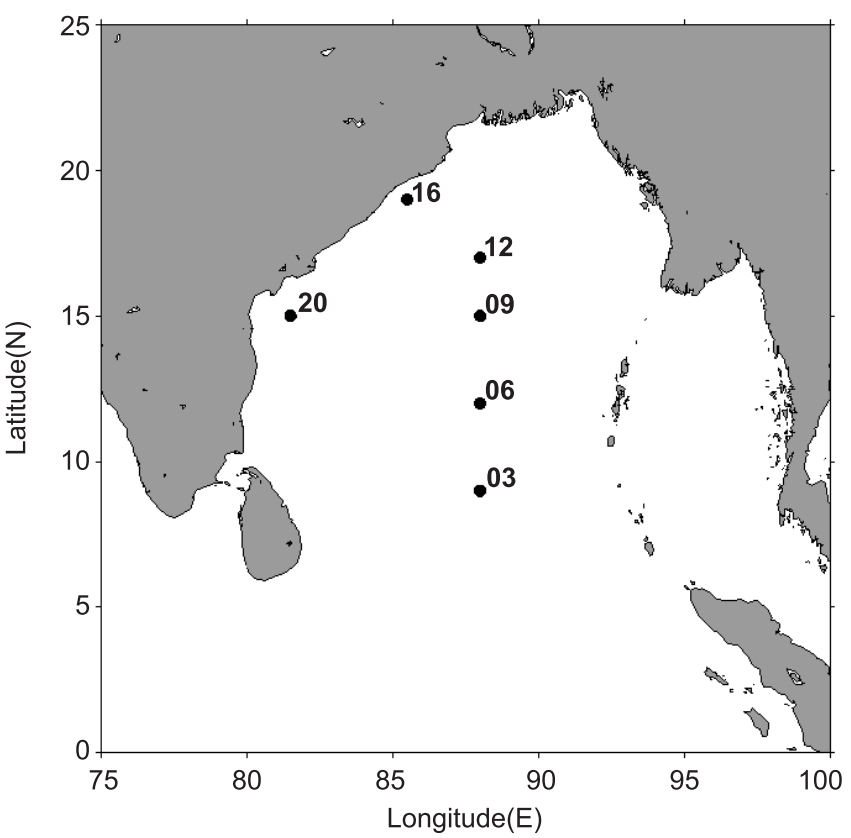

Figure 1. Map of the study site showing sampling stations in the Bay of Bengal.

(Shetye et al 1991). The Bay is slightly more oxygenated compared to the Arabian Sea.

\subsection{Collection of samples}

Suspended particulate matter (SPM) samples were collected from 8 discrete depths (2 to $1000 \mathrm{~m}$ ) at six locations (figure 1) using Niskin water samplers (301) attached to the CTD rosette system during the 166th cruise of ORV Sagar Kanya in the Bay of Bengal in the summer monsoon of 2001. Immediately after collection, the water samples (4 to 10l) were filtered through precombusted $\left(450^{\circ} \mathrm{C}, 4 \mathrm{~h}\right) 47 \mathrm{~mm} \mathrm{GF} / \mathrm{F}$ glass fibre filters $(0.7 \mu \mathrm{m}$ pore size $)$ for the analysis of particulate organic carbon (POC), particulate nitrogen $(\mathrm{PN})$ and amino sugars (AS) concentration and composition.

\subsection{Analysis of samples}

The SPM samples were de-carbonated overnight using fuming $\mathrm{HCl}$ in a desiccator (Ferrari et al 2003), dried at $50^{\circ} \mathrm{C}$ and then analyzed for particulate organic carbon (POC) and particulate nitrogen (PN) using a Perkin Elmer Elemental analyzer $2400 \mathrm{CHN}$ analyzer. The precision of the methods was better than $7 \%$.

Filters for amino sugar analysis were transferred to ampoules, and $2 \mathrm{ml}$ of $6 \mathrm{~N} \mathrm{HCl}$ were added to each ampoule. The ampoules were flushed with nitrogen gas and sealed. Samples were hydrolyzed for $22 \mathrm{~h}$ at $110^{\circ} \mathrm{C}$ (Bhosle et al 2005). The samples were cooled and neutralized using $\mathrm{NaOH}$. An 
aliquot was then reacted with $o$-phthaldialdehyde (OPA)-mercaptoethanol reagent and then analyzed by high performance liquid chromatograph (HPLC) as described previously (Lindroth and Mopper 1979; Bhosle et al 2005). This method has been routinely used to analyze amino sugars in sedimenting particles and sediments (Belluomini et al 1986; Haake et al 1992; Jennerjahn and Ittekkot 1997; Hashimoto et al 1998; Gupta and Kawahata 2000; Takano et al 2004).

An HPLC system (Shimadzu, Model 1) consisting of quaternary pump, degasser, autoinjector, column oven, fluorescence detector, ODS guard column $(4.6 \mathrm{~mm}$ ID, $4.5 \mathrm{~cm}$ length, $10 \mu \mathrm{m}$ particle size) and reversed phase Shim-Pack HRC-ODS analytical column $(4.6 \mathrm{~mm}$ ID, $15 \mathrm{~cm}$ length, $5 \mu \mathrm{m}$ particle size) was used. A binary solvent system consisting of $50 \mathrm{mM}$ sodium acetate buffer (pH 6.5) containing $3 \%$ of tetrahydrofuran as solvent $\mathrm{A}$ and methanol as solvent B was used to separate the AS. Using this solvent system the two AS, glucosamine (GLU-N) and galactosamine (GAL-N) could be separated from the standard mixture (figure $2 \mathrm{~A}$, B, C) and SPM samples (figure 2D). The sum of the concentrations of the two identified AS GLU$\mathrm{N}$ and GAL-N is expressed as total hydrolysable amino sugars (AS). The precision of the method based on 5 replicates was \pm 4 to $6 \%$.

\section{Results and discussion}

$\mathrm{POC}$ and $\mathrm{PN}$ concentrations varied in the range of 2.43 to $14.25 \mu \mathrm{mol} / \mathrm{l}$ and 0.11 to $2.84 \mu \mathrm{mol} / \mathrm{l}$, respectively (table 1 ). The surface values of POC and PN increased gradually from south $(6.97 \mu \mathrm{mol} / \mathrm{l}$ POC; $0.97 \mu \mathrm{mol} / \mathrm{l} \mathrm{PN})$ to north $(11.06 \mu \mathrm{mol} / 1 \mathrm{POC}$ and $1.23 \mu \mathrm{mol} / \mathrm{l} \mathrm{PN})$ for the deep oceanic stations (\#03 to \#12). A similar trend was recorded for the near shore stations (\#16 and \#20). The observed spatial variability in the POC and PN in surface samples may be due to differences in the input of autochonthous or allochonthous organic matter at these locations of the Bay. For example, it is possible that the northern stations may have received more inputs of terrestrial material due to their proximity to the area receiving river run-off that might have resulted in relatively higher abundance of organic matter at the northern stations. The POC concentrations reported here are relatively lower than those reported earlier for the Bay (Radhakrishna et al 1978; Bhattathiri et al 1980; Nandakumar et al 1987). This is due to different analytical methods used for the analysis of POC. Nevertheless, our POC concentrations are similar to those reported for other oceanic regions (Gordon et al 1979; Gordon and Cranford 1985).
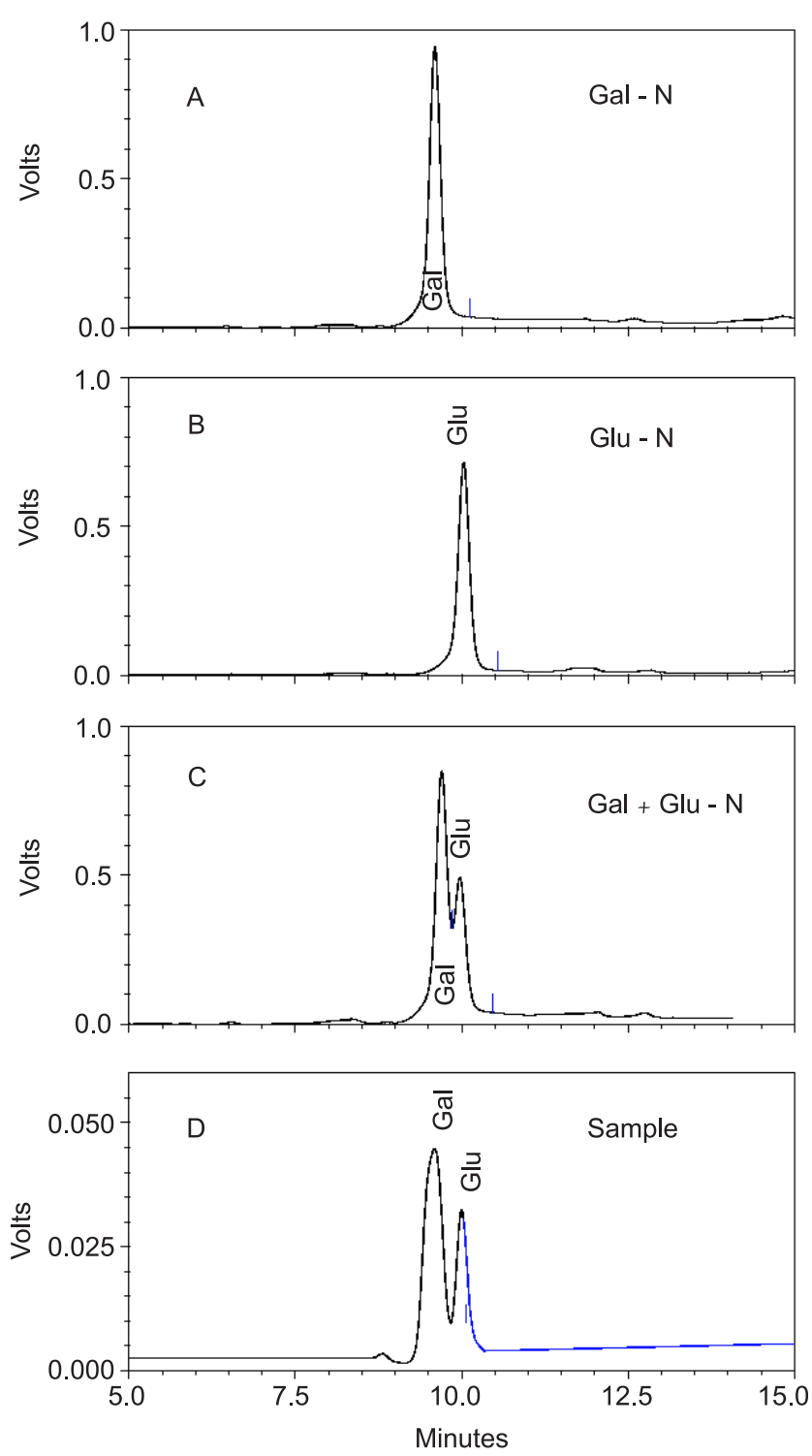

Figure 2. Chromatograms showing peaks of amino sugars separation of galactosamine (A), glucosamine (B), a mixture of galactosamine and glucosamine $(\mathrm{C})$ and presence of these two amino sugars in a SPM sample (D) of the Bay.

Depth related variations were also observed at these stations. Both POC and PN were found to be higher in the surface waters and decreased with increasing depth but with some exceptions (table 1). This suggests utilization of these compounds by the mid water column organisms (Gordon and Cranford 1985). In contrast, at station 9, the distribution of both POC and PN was not influenced by the depth. This probably indicates a balance in the supply and utilization of these compounds. At station 12, concentrations of $\mathrm{POC}$ and $\mathrm{PN}$ were found to be relatively higher perhaps due to the inputs it receives from the rivers Ganges-Brahmaputra, Mahanadi, Pennar and Cauvery. At stations \#03, 06 and 12 the concentrations of POC and PN decreased in the upper 
Table 1. Distribution of POC, PN, C/N ratio, AS, AS-C\%, AS-N\% and $G L U-N / G A L-N$ in the Bay.

\begin{tabular}{|c|c|c|c|c|c|c|c|c|c|}
\hline Station & Position & $\begin{array}{l}\text { Depth } \\
(\mathrm{m})\end{array}$ & $\begin{array}{c}\mathrm{POC} \\
\mu \mathrm{mol} / 1\end{array}$ & $\begin{array}{c}\mathrm{PN} \\
\mu \mathrm{mol} / \mathrm{l}\end{array}$ & $\begin{array}{l}\mathrm{C} / \mathrm{N} \\
\text { ratio }\end{array}$ & $\begin{array}{c}\mathrm{AS} \\
\mathrm{nmol} / \mathrm{l}\end{array}$ & $\mathrm{AS}-\mathrm{C} \%$ & AS-N\% & $\begin{array}{c}\text { GLU-N:GAL-N } \\
\text { Molar }\end{array}$ \\
\hline \multirow[t]{8}{*}{ \#03 } & \multirow[t]{8}{*}{$9^{\circ} \mathrm{N} 88^{\circ} \mathrm{E}$} & 2 & 6.97 & 0.97 & 7.1 & 10.4 & 0.57 & 0.64 & 0.35 \\
\hline & & 10 & 4.96 & 0.65 & 7.6 & 7.7 & 0.60 & 0.70 & 0.45 \\
\hline & & 30 & 5.86 & 0.78 & 7.5 & 7.2 & 0.48 & 0.55 & 0.36 \\
\hline & & 60 & 4.27 & 0.55 & 7.8 & 3.4 & 0.30 & 0.33 & 0.11 \\
\hline & & 100 & 4.08 & 0.52 & 7.8 & 4.2 & 0.39 & 0.71 & 0.29 \\
\hline & & 300 & 5.13 & 0.73 & 7.0 & 2.5 & 0.19 & 0.69 & 0.04 \\
\hline & & 500 & 4.49 & 0.60 & 7.5 & 2.0 & 0.17 & 0.50 & 0.06 \\
\hline & & 1000 & 7.92 & 1.17 & 6.8 & 3.3 & 0.16 & 0.65 & - \\
\hline \multirow[t]{8}{*}{ \#06 } & \multirow[t]{8}{*}{$12^{\circ} \mathrm{N} 88^{\circ} \mathrm{E}$} & 2 & 6.94 & 0.95 & 7.3 & 12.7 & 0.71 & 2.37 & 0.43 \\
\hline & & 10 & 5.63 & 0.86 & 6.5 & 9.1 & 0.62 & 1.04 & 0.43 \\
\hline & & 30 & 5.67 & 0.85 & 6.7 & 5.2 & 0.35 & 0.60 & 0.38 \\
\hline & & 60 & 4.79 & 0.89 & 5.4 & 3.9 & 0.31 & 0.33 & 0.34 \\
\hline & & 100 & 6.24 & 0.94 & 6.6 & 7.9 & 0.49 & 0.70 & 0.30 \\
\hline & & 300 & 6.49 & 0.89 & 7.4 & 3.6 & 0.21 & 0.35 & 0.07 \\
\hline & & 500 & 6.08 & 0.79 & 7.6 & 3.9 & 0.25 & 0.87 & 0.70 \\
\hline & & 1000 & 7.63 & 1.03 & 7.4 & 5.7 & 0.29 & 0.89 & 0.35 \\
\hline \multirow[t]{7}{*}{ \#09 } & \multirow[t]{7}{*}{$15^{\circ} \mathrm{N} 88^{\circ} \mathrm{E}$} & 2 & 6.53 & 0.96 & 6.7 & 7.6 & 0.45 & 1.16 & 0.15 \\
\hline & & 10 & 6.45 & 0.94 & 6.8 & 6.8 & 0.40 & 0.55 & 0.26 \\
\hline & & 30 & 6.60 & 1.14 & 5.8 & 3.2 & 0.19 & 0.29 & 0.73 \\
\hline & & 60 & 7.30 & 0.78 & 7.5 & 4.7 & 0.25 & 0.56 & 0.17 \\
\hline & & 100 & 6.77 & 0.71 & 9.6 & 2.0 & 0.11 & 0.26 & 0.38 \\
\hline & & 300 & 6.54 & 0.68 & 9.5 & 1.2 & 0.07 & 0.14 & 0.41 \\
\hline & & 500 & 6.49 & 0.81 & 8.0 & 1.1 & 0.07 & 0.20 & 0.30 \\
\hline \multirow[t]{8}{*}{ \#12 } & \multirow[t]{8}{*}{$17^{\circ} \mathrm{N} 88^{\circ} \mathrm{E}$} & 2 & 11.06 & 1.23 & 9.0 & 5.4 & 0.19 & 0.67 & 0.86 \\
\hline & & 10 & 13.44 & 1.41 & 9.5 & 10.3 & 0.30 & 0.73 & 1.35 \\
\hline & & 30 & 13.53 & 1.48 & 9.1 & 17.5 & 0.50 & 1.38 & 0.99 \\
\hline & & 60 & 11.53 & 1.27 & 9.1 & 4.1 & 0.14 & 0.45 & 0.71 \\
\hline & & 100 & 9.53 & 1.11 & 8.6 & 8.7 & 0.35 & 0.95 & 0.69 \\
\hline & & 300 & 14.25 & 1.63 & 8.8 & 5.4 & 0.14 & 0.54 & 0.76 \\
\hline & & 500 & 9.78 & 1.52 & 6.4 & 2.4 & 0.10 & 0.24 & 1.03 \\
\hline & & 1000 & 12.36 & 2.84 & 4.4 & 0.5 & 0.01 & 0.05 & 0.57 \\
\hline \multirow[t]{7}{*}{$\# 16$} & \multirow[t]{7}{*}{$19^{\circ} \mathrm{N} 85^{\circ} \mathrm{E}$} & 2 & 6.58 & 0.78 & 8.4 & 0.8 & 0.05 & 0.06 & 0.72 \\
\hline & & 10 & 6.25 & 0.57 & 10.9 & 1.7 & 0.10 & 0.08 & 0.39 \\
\hline & & 30 & 4.17 & 0.50 & 8.3 & 1.2 & 0.11 & 0.08 & 0.57 \\
\hline & & 60 & 3.50 & 0.50 & 7.0 & 0.9 & 0.10 & 0.08 & 0.62 \\
\hline & & 100 & 4.0 & 0.43 & 9.3 & 1.2 & 0.12 & 0.12 & 0.47 \\
\hline & & 300 & 3.50 & 0.36 & 9.8 & 1.3 & 0.14 & 0.16 & 0.24 \\
\hline & & 500 & 3.08 & 0.36 & 8.6 & 0.4 & 0.05 & 0.08 & 0.34 \\
\hline \multirow[t]{8}{*}{$\# 20$} & \multirow[t]{8}{*}{$15^{\circ} \mathrm{N} 81^{\circ} \mathrm{E}$} & 2 & 4.90 & 0.38 & 12.7 & 4.9 & 0.39 & 0.97 & 0.28 \\
\hline & & 10 & 5.34 & 0.42 & 12.8 & 2.3 & 0.17 & 0.31 & 0.21 \\
\hline & & 30 & 4.19 & 0.47 & 8.9 & 2.2 & 0.20 & 0.27 & 0.17 \\
\hline & & 60 & 4.27 & 0.28 & 14.8 & 1.8 & 0.16 & 0.23 & 0.24 \\
\hline & & 100 & 4.0 & 0.23 & 17.8 & 1.4 & 0.14 & 0.20 & 0.25 \\
\hline & & 300 & 3.81 & 0.11 & 33.9 & 0.6 & 0.06 & 0.11 & 0.32 \\
\hline & & 500 & 3.89 & 0.44 & 8.9 & 0.9 & 0.09 & 0.18 & 0.28 \\
\hline & & 1000 & 2.43 & 1.07 & 2.3 & 0.9 & 0.14 & 0.27 & 0.44 \\
\hline
\end{tabular}

$500 \mathrm{~m}$ of the water column and then increased again at $1000 \mathrm{~m}$. It was interesting to note that the concentrations of POC and PN recorded at $1000 \mathrm{~m}$ were relatively higher than those recorded at the surface waters of these stations. At $1000 \mathrm{~m}$ organic matter had elevated levels of $\mathrm{AS}$ and low $\mathrm{C} / \mathrm{N}$ ratio. This indicates that the organic matter present at this depth was derived from marine phytoplankton and bacteria (Karl and Knauer 1984). Concentrations of POC and PN showed significant positive relationship $(R=0.89, n=44)$ thereby suggesting their common origin.

$\mathrm{C} / \mathrm{N}$ ratio is a useful tool to assess the nature of organic matter. The rationale behind this approach is that the fresh and degraded organic matter has low and high $\mathrm{C} / \mathrm{N}$ ratio, respectively. For example, fresh phytoplankton and bacteria exhibit an average $\mathrm{C} / \mathrm{N}$ ratio of 7 and 4, respectively (Lee and Furhman 1987; Nelson and Robertson 1993). The $\mathrm{C} / \mathrm{N}$ ratio is found to increase with the microbial 


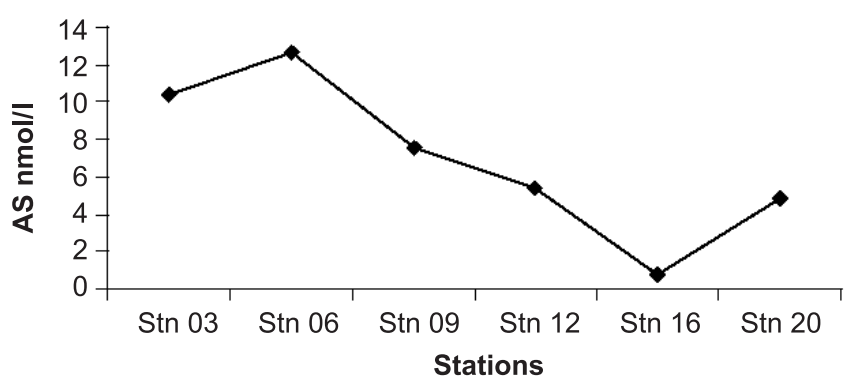

Figure 3. Spatial variation in the amino sugar concentration in the surface samples of Bay of Bengal.

decomposition of organic matter, since nitrogen is utilized faster than the carbon (Lehmannn et al 2002). Similarly, the organic matter derived from terrestrial plants has high $(>24) \mathrm{C} / \mathrm{N}$ ratio (Elser et al 2000). Most of the values of the $\mathrm{C} / \mathrm{N}$ ratio of the SPM samples of the Bay are in the range of values recorded for phytoplankton and bacteria. High $\mathrm{C} / \mathrm{N}$ ratio $(>9)$ of the surface $\mathrm{SPM}$ at stations 12 and 20 indicate that the organic matter at these stations was relatively more degraded. Furthermore, a decrease in $\mathrm{C} / \mathrm{N}$ ratio at $1000 \mathrm{~m}$ was also recorded at these two stations indicating the occurrence of relatively fresh organic matter at this depth (Nelson and Robertson 1993). The range of $\mathrm{C} / \mathrm{N}$ values recorded for the stations sampled in the Bay suggests that organic matter was mostly derived from phytoplankton and bacteria.

Total concentrations of the AS ranged between 0.4 and $17.5 \mathrm{nmol} / \mathrm{l}$ (table 1 ). There were apparent variations in the AS concentrations with respect to location and the depth (figure 4). Distribution of AS in the Bay indicates that the concentrations of the AS increased from north to south (figure 3). These AS concentrations observed for the Bay are higher than those reported for other seas and oceans of the world. For example, Benner and Kaiser (2003) reported large variations (0.18 to $1.7 \mathrm{nmol} / \mathrm{l}$ ) in total hydrolysable amino sugars of the SPM samples collected from various depths of the Pacific Ocean. The AS accounted for 0.01 to $0.71 \%$ of $\mathrm{POC}$ and 0.05 to $2.37 \%$ of $\mathrm{PN}$ in the Bay (table 1). These values are in the range of values ( 0.1 to $1.5 \%$ of organic carbon) reported for plankton and the suspended particulate matter collected from the Pacific Ocean (Benner and Kaiser 2003). The rapid decrease in the concentrations and the $\% \mathrm{AS}-\mathrm{C} / \mathrm{OC}$ and $\mathrm{AS}-\mathrm{N} / \mathrm{PN}$ with increasing depth imply that these compounds were rapidly recycled in the upper ocean. AS concentrations showed fairly good correlation with POC $\left(R^{2}=0.61 ; n=43\right)$ and $\mathrm{PN}\left(R^{2}=0.64 ; n=43\right)$ suggesting their common origin.

HPLC method is routinely employed for the analysis of AS in sedimenting particles and sediments (Belluomini et al 1986; Haake et al 1992;
Jennerjahn and Ittekkot 1997; Hashimoto et al 1998; Gupta and Kawahata 2000; Takano et al 2004). Using this method glucosamine (GLU-N) and galactosamine (GAL-N) were detected in the SPM samples collected from different stations sampled in the Bay of Bengal (figure 2). Concentrations of the GLU-N and GAL-N in the SPM samples varied from 0.1 to $8.7 \mathrm{nmol} / \mathrm{l}$ and 0.29 to $8.9 \mathrm{nmol} / \mathrm{l}$, respectively (figure 4). Both the AS were also abundant in the SPM of other seas and oceans, the pure cultures of micro-organisms and the natural assemblages of organisms collected from various environments (Benner and Kaiser 2003). This suggests their widespread distribution and similar reactivities. It was interesting to note that the concentrations of both GLU-N and GAL-N decreased rapidly with the increasing depth suggesting their utilization. This AS distribution pattern contradicts the distribution pattern of these compounds observed in the sedimenting particles (Belluomini et al 1986; Haake et al 1992; Hashimoto et al 1998; Gupta and Kawahata 2000). In sedimenting particles the concentrations of amino sugars generally increased with water depth. The apparent difference may be due to the fact that the sedimenting particles are generally derived from large particles such as faecal pellets and faecal matter produced by chitinaceous zooplankton and/or contamination due to the chitinaceous swimmers that get caught in the traps.

The GLU-N/GAL-N ratio is a useful parameter to differentiate the relative inputs of the organic matter derived from zooplankton and micro-organisms in marine waters (Muller et al 1986; Haake et al 1993; Benner and Kaiser 2003). This approach is based on the fact that GLU-N content is very high in zooplankton, whereas, it is relatively low in micro-organisms. Our samples were relatively rich in GAL-N compared to GLU-N (figure 2). As a result, our GLU-N/GAL-N ratios are lower (0.04 to 1.4) than those (1 to 2.5) reported by Benner and Kaiser (2003) for the SPM samples collected from the Pacific Ocean. Similarly, our GLU-N/GAL-N ratios are also lower than those (6.3 to 8.69) recorded for the SPM of the Kara Sea (Unger et al 2005). The GLU-N/GAL-N ratio for the SPM of the Bay of Bengal samples is $<2$ thereby suggesting that the organic matter was mostly derived from heterotrophic microorganisms. Absence of high (>4) GLU-N/GAL-N ratio also indicated that the contribution of chitin, a polymer of the $\mathrm{N}$-acetyl glucosamine, produced by many marine organisms, to the marine organic matter was relatively very poor. Conversely, Muller et al (1986) reported a very high abundance of GLU-N and could not detect GAL-N in the suspended particles of the south Atlantic due to the abundance of zooplankton in the study area. 

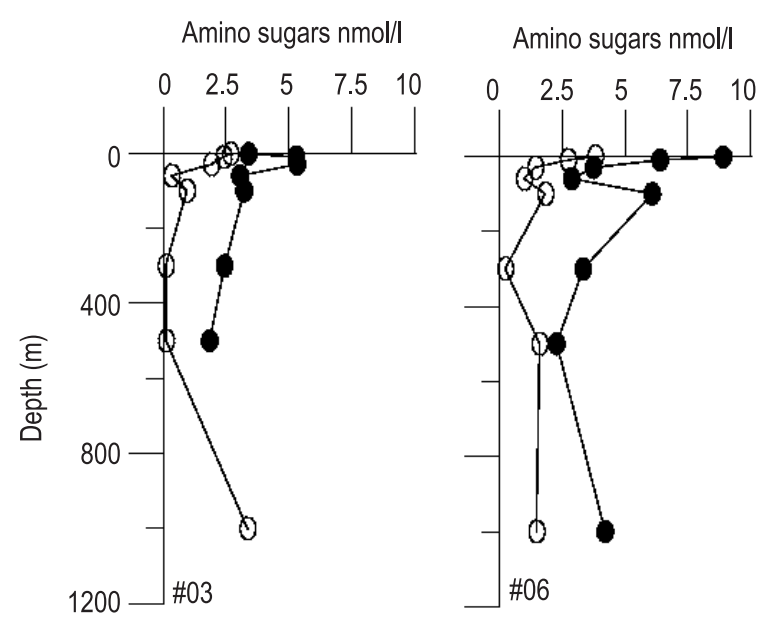

Amino sugars $\mathrm{nmol} / \mathrm{l}$
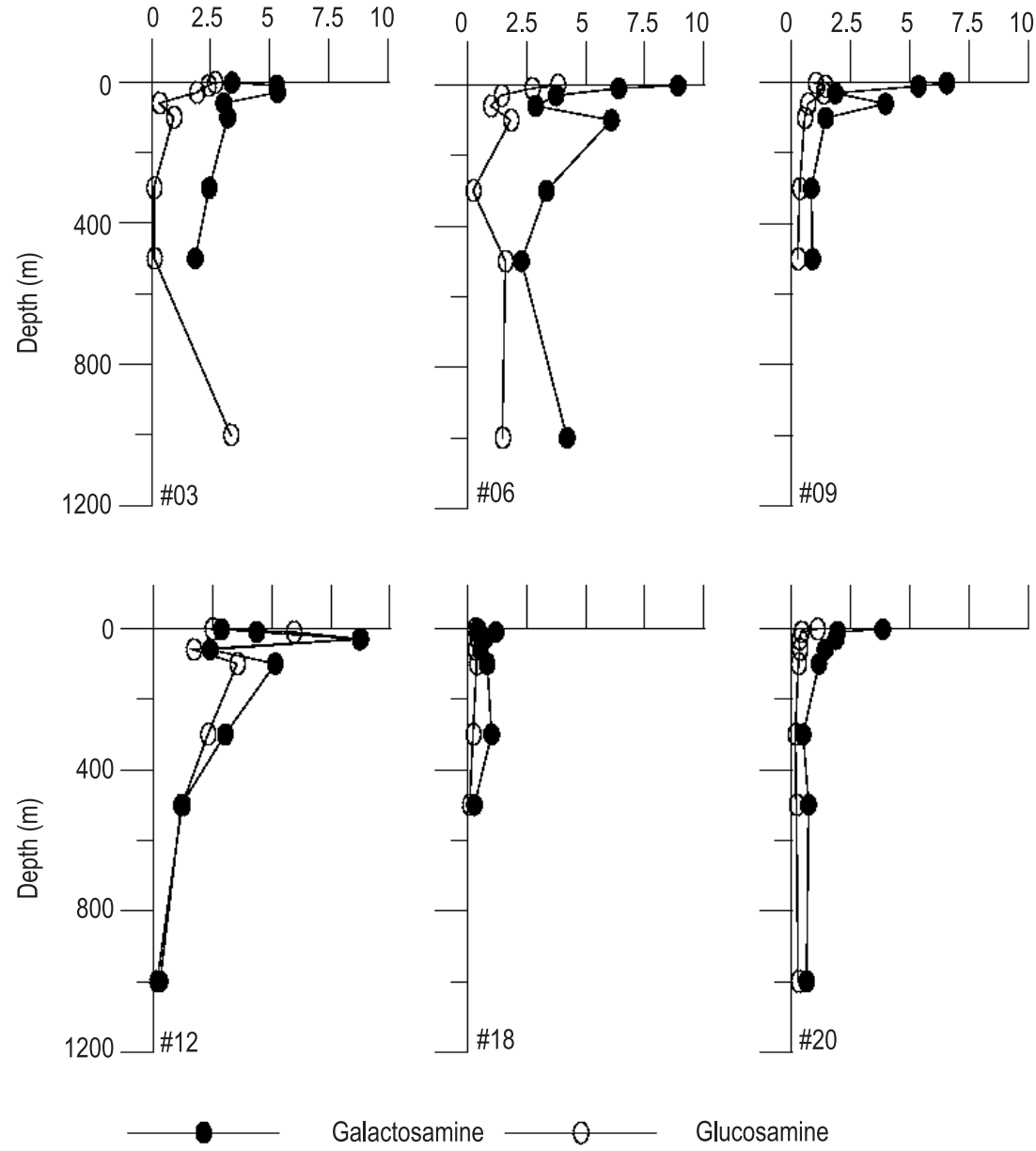

Figure 4. Depth profiles of galactosamine and glucosamine concentrations of the Bay of Bengal.

The concentrations of both GLU-N and GAL-N decreased with depth, however the decrease in the concentrations of GLU-N was more rapid. This results in decreasing GLU-N/GAL-N ratio with the increase in water depth. This is probably due to different sources of amino sugars and/or preferential degradation of GLU-N. It is argued that the decreasing GLU-N/GAL-N ratio is more indicative of preferential degradation of GLU-N than of different sources (Unger et al 2005). They reported that low GLU-N/GAL-N ratios were associated with reduced values of reactive index. In order to support this it was further argued that glucose as a major building block of GLU-N is an important storage compound whereas GAL-N is derived from galactose that is a structural monomer in algae. It is well documented that the storage polymers are preferentially degraded compared to structural polymers (Ittekkot et al 1982; Hernes et al 1996; Unger et al 2005). In view of this, it is hypothesized that the preferential utilization of GLU-N rather than different sources may be responsible for the observed low GLU-N/GAL-N ratio in our samples. This conclusion is also supported by a fairly good correlation $(R=0.76 ; n=44)$ between these two amino sugars suggesting a common origin.

Amino sugars are unique among the carbohydrates due to the presence of nitrogen atoms in their molecules. They are important components of the marine N-cycle. For example, total hydrolysable amino acids (THAA-N) account for a much greater percentage of marine organic nitrogen $(42-72 \%)$ than amino sugars but amino sugar concentrations decrease more rapidly with depth than amino acid concentrations. This suggests that amino sugars are more efficiently recycled in the upper water column (Benner 2002; Benner and Kaiser 2003). Similarly, the decrease in amino sugar concentrations was greater than that recorded for the POC. This indicates that amino sugars are considerably more reactive than $\mathrm{POC}$ in the upper ocean waters.

\section{Summary}

Amino sugars, which are the unique sugars with a nitrogen molecule, were found to be the important 
constituents of the organic matter in the Bay of Bengal. Both GLU-N and GAL-N were present at all the stations. Rapid decrease in amino sugar concentration, AS-C\% and AS-N\% clearly suggested that the compounds are rapidly mineralized in the water column. Low GLU-N/GAL-N ratio $(<2)$ indicates microbial detritus and not chitin as the major source of amino sugars in the Bay.

\section{Acknowledgements}

The authors thank Dr Satish R Shetye, the Director NIO, for his support and encouragement. We appreciate very much the help of Dr Prasanna Kumar, Chief Scientist of the SK cruise 166, as well as other cruise participants in collecting the samples, and Mr A P Selvam in running HPLC for amino sugar analysis. We are grateful to the Department of Ocean Development, Government of India, New Delhi for providing financial assistance to carry out these studies in the Bay of Bengal under the BOBPS Project. The authors thank the three anonymous referees and Dr J S Ray, the handling editor, for their critical but useful comments on the earlier version of the manuscript.

\section{References}

Belluomini G, Brancaj M, Calderoni G and Schnitzer M 1986 Distribution and geochemical significance of amino acids and amino sugars in a clay suite of the PliocenePleistocene age from central Italy; Org. Geochem. 9 127-133.

Benner R 2002 Chemical composition and reactivity; In: Biogeochemistry of marine dissolved organic matter (eds) Hansell D and Carlson C (Academic) pp. 59-90.

Benner R and Kaiser K 2003 Abundance of amino sugars and peptidoglycan in marine particulate and dissolved organic matter; Limnol. Oceanogr. 48 118-128.

Bhattathiri P M A, Devassy V P and Radhakrishna K 1980 Primary production in the Bay of Bengal during southwest monsoon of 1978; Mahasagar - Bulletin of the National Institute of Oceanography 13 315-323.

Bhosle N B and Dhople V M 1988 Distribution of some biochemical compounds in the sediments of the Bay of Bengal; Chem. Geol. 67 341-352.

Bhosle N B and Wagh A B 1989 Particulate carbohydrates in the Arabian Sea; Oceanol. Acta 12 57-63.

Bhosle N B, Sankaran P D and Wagh A B 1992 Monosaccharide composition of suspended particles from the Bay of Bengal; Oceanol. Acta 15 279-286.

Bhosle N B, Garg A, Fernandes L and Citon P 2005 Dynamics of amino acids in the conditioning film developed on glass panels immersed in the surface seawaters of Dona Paula Bay; Biofouling 21 99-107.

Brock T D, Madigan M T, Martinko J M and Parker J 1994 Biology of microorganisms, 7th edn., Prentice Hall.

Elser J J, Fagan W F, Denno R F, Dobberfuhl D R, Folarin A, Huberty A, Interlandi S, Kilham S S, McCauley E, Schulz K L, Siemann E H and Sterner R W
2000 Nutritional constraints in terrestrial and freshwater food webs; Nature 408 578-580.

Ferrari G M, Franco G Bo and Babin M 2003 Geo-chemical and optical characterizations of suspended matter in European coastal waters; 57 17-24.

Gordon D C, Wangersky P J and Sheldon R W 1979 Detailed observations on the distribution and composition of particulate organic material at two stations in the Sargasso Sea; Deep-Sea Res. 26 1083-1092.

Gordon D C Jr and Cranford P J 1985 Detailed distribution of dissolved and particulate organic matter in the Arctic Ocean and comparison with other oceanic regions; DeepSea Res. 32 1221-1232.

Gupta L P and Kawahata H 2000 Amino acid and hexosamine composition and flux of sinking particulate matter in the equatorial Pacific at $175^{\circ} \mathrm{E}$ longitude; Deep-Sea Res. I 47 1937-1960.

Haake B, Ittekkot V, Ramaswamy V, Nair R R and Honjo S 1992 Fluxes of amino acids and hexosamines to the deep Arabian Sea; Mar. Chem. 40 291-314.

Haake B, Ittekkot V, Honjo S and Manganini S 1993 Amino acids hexosamines and Carbohydrate fluxes to the deep Subartic Pacific (Station P); Deep-Sea Res. 40 547-560.

Hashimoto S, Maita Y, Yanada M and Takahashi K 1998 Annual and seasonal variations of amino acid and hexosamine fluxes in the deep Bering Sea and the deep central Subarctic Pacific; Deep-Sea Res. 45 1029-1051.

Hernes P J, Hedges J I, Peterssons M L, Wakeham S G and Lee C 1996 Neutral carbohydrates of particulate material in the central equatorial Pacific; Deep-Sea Res. II 43 1181-1204.

Ittekkot V, Dengens E T and Brockmann U 1982 Monosaccharide composition of acid - hydrolyzable carbohydrates in particulate matter during a phytoplankton bloom; Limnol. Oceanogr. 27 770-776.

Jennerjahn T C and Ittekkot V 1997 Organic matter in sediments in the mangrove areas and adjacent continental margin of Brazil: 1 Amino Acids and Hexosamine; Oceanol. Acta 20 359-369.

Karl D M and Knauer G A 1984 Vertical distribution transport and exchange of carbon in the northeast Pacific Ocean: evidence for multiple zones of biological activity; Deep-Sea Res. 31 221-243.

Kumar Prasanna S, Muraleedharan P M, Prasad T G, Gauns M, Ramaiah N, De'Souza S N, Sardesai S and Madhupratap M 2002 Why is the Bay of Bengal less productive during summer monsoon compared to the Arabian Sea?; Geophys. Res. Lett. 292235.

Kumar S, Ramesh R, Bhosle N B, Sardesai S and Sheshshayee M S 2004 Natural isotopic composition of nitrogen in suspended particulate matter in the Bay of Bengal; Biogeosciences 1 63-70.

Lee S and Furhman J D 1987 Relationships between biovolume and biomass of naturally derived marine bacterioplankton; Applied Env. Microbiol. 1298-1303.

Lehmann M F, Bernasconi S M, Barbieri A and McKenzie J A 2002 Preservation of organic matter and alteration of its carbon and nitrogen isotope composition during simulated and in situ early sedimentary diagenesis; Geochim. Cosmochim. Acta 66 3573-3584.

Lindroth P and Mopper K 1979 High performance liquid chromatographic determination of subpicomole amounts of aminoacids by precolumn fluorescence derivatization with o-phthalialdehyde; Anal. Chem. 51 1667-1674.

Madhupratap M, Gauns M, Ramaiah N, Kumar P S, Muraleedharan P M, De'Sousa S N, Sardesai S and Muraleedharan U 2003 Biogeochemistry of the Bay of Bengal: physical, chemical and primary productivity characteristics of the central and western Bay of Bengal 
during summer monsoon 2001; Deep-Sea Res. II 50 881-896.

McCarthy M, Pratum T, Hedges J I and Benner R 1997 Chemical composition of dissolved organic nitrogen in the ocean; Nature 390 150-154.

Muller P J, Suess E and Ungerer C A 1986 Amino acids and amino sugars of surface particulate and sediment trap material from waters of the Scotia Sea; Deep-Sea Res. 33 819-838.

Muzzarelli R 1977 Chitin (Oxford, New York, Toronto, Sydney, Paris, Frankfurt: Pergamon Press).

Nandakumar K, Venkat K and Bhosle N B 1987 Distribution of particulate organic carbon in the central Bay of Bengal; Proc. Indian Acad. Sci. (Earth Planet. Sci.) 96 189-193.

Nelson J R and Robertson C Y 1993 Detrital spectral absorption: Laboratory studies of visible light effects on phytodetritus absorption, bacterial spectral signal, and comparison to field measurements; J. Mar. Res. 51 181-207.

Radhakrishna K, Bhattathiri P M A and Devassy V P 1978 Primary productivity of the Bay of Bengal during August-September 1976; Indian J. Mar. Sci. 7 94-98.

Rao S 1985 Distribution of suspended particulate matter in the waters of eastern continental margin of India; Indian J. Mar. Sci. 14 14-19.
Sharon N 1965 Microorganisms, plants, and invertebrates, In: The amino sugars: the chemistry and biology of compounds containing amino sugars (eds) Balazs E A and Jeanloz R W (Academic) Pp. 1-45.

Shetye S R, Shenoi S S C, Gouveia A D, Michael G S, Sundar D and Nampoothiri G 1991 Wind-driven coastal upwelling along the western boundary of the Bay of Bengal during the southwest monsoon; Cont. Shelf Res. 11 1397-1408.

Subramanian V 1993 Sediment load of Indian Rivers; Curr. Sci. 64 928-930.

Takano Y, Gupta L P, Kawahata H, Marumo K, Ishikawa Y and Kobayashi K 2004 Glucosamine and Galactosamine in terrestrial organic matter and their correlation with other biochemical indicators; Bull. Chem. Soc. Japan $\mathbf{7 7}$ 729-732.

Unger D, Ittekkot V, Schäfer P and Tiemann J 2005 Biogeochemistry of particulate organic matter from the Bay of Bengal as discernible from hydrolysable neutral carbohydrates and amino acids; Marine Chemistry 96 $155-184$

Vinayachandran P N and Mathew S 2003 Phytoplankton bloom in the Bay of Bengal during the northeast monsoon and its intensification by cyclone; Geophys. Res. Lett. 301572. 